\title{
Mushroom Production Benefits, Status, Challenges and Opportunities in Bangladesh: A Review
}

\author{
Jannatul Ferdousi ${ }^{1}$, Zabid Al Riyadh ${ }^{2}$, Md. Iqbal Hossain ${ }^{2^{*}}$, Satya Ranjan Saha ${ }^{2}$ \\ and Mohammad Zakaria ${ }^{1}$ \\ ${ }^{1}$ Department of Horticulture, Bangabandhu Sheikh Mujibur Rahman Agricultural University, \\ Gazipur, Bangladesh.
${ }^{2}$ Department of Agroforestry and Environment, Bangabandhu Sheikh Mujibur Rahman \\ Agricultural University, Gazipur, Bangladesh.
}

\begin{abstract}
Authors' contributions
This work was carried out in collaboration among all authors. Authors JF and ZAR designed the conceptual framework of study, performed relevant literature search and wrote the initial draft of the manuscript. Author MIH drawn the pictures and assisted in the formulation of tabular constituents. Authors SRS and MZ reviewed and rewrote the manuscript. All authors read and approved the final manuscript.

Article Information

DOI: $10.9734 / A R R B / 2019 / v 34 i 630169$ Editor(s):

(1) Dr. Md. Torequl Islam, Federal University of Piaui, Brazil. Reviewers:

(1) Emilio Martínez Ibarra, Universidad de Granada, Spain

(2) K. Immaculate Jeyasanta, India. Complete Peer review History: http://www.sdiarticle4.com/review-history/55161
\end{abstract}

\section{ABSTRACT}

Compacted information on mushroom cultivation in relation to production, performance, problems and prospects is very important for developing this sector. So, the aim of the review paper is to compile information on mushroom cultivation in Bangladesh. Mushroom production is increasing due to high demand of domestic market and export potentiality. In Bangladesh 40000 MT mushrooms are produced during 2018-19. Oyster, Reishi, Milky, Button, Straw and Shiitake mushrooms are most preferable species and cultivated by the farmers; but the maximum cultivation is confined to oyster mushroom (Pleurotus spp.) which are grown throughout the year. Mostly young aged educated people and rural women are adopting mushroom farming as commercial basis in Bangladesh. The study revealed that mushroom production is easy work because it requires only a little technical efficiency and a highly profitable agribusiness as evident for its lucrative benefit cost ratio (BCR 1.55-4.25). Although mushrooms production increased, there are some problems 
confronting by the mushroom growers during cultivation and marketing including lack of cultivation house, unavailability of good spawn, capital shortage, lack of equipment's, lack of available market and promotion in local level, lack of storage facilities etc. which are needed to be addressed for further development of this sector. There is enormous opportunity of expanding mushroom farming throughout the country. Considering the country's limited land, over and unemployed population, strengthening the production of mushroom could be one of the sustainable options for the development of rural economy. Development of this sector would also improve the diversified business and employment opportunities both in the rural and semi-urban areas.

Keywords: Mushroom cultivation; oyster; problems; marketing; prospects; rural economy.

\section{INTRODUCTION}

Mushroom is one of the most diverse organisms on earth and since primitive times have played a vital role in human welfare [1]. A mushroom is the fleshy and spore-bearing fruiting body of a fungus and belongs to the class Basidiomycetes under the order Agaricales in fungal classification, typically produced above the ground on soil or on its food substrate. It has been universally used as a food and medicine by different civilizations since ancient time due to its delicious taste, flavor, dietetic qualities and several medicinal properties $[1,2,3]$. The fresh mushroom contains about $85-90 \%$ moisture, $3 \%$ protein, $4 \%$ carbohydrates, $0.3-0.4 \%$ fats and $1 \%$ minerals and vitamins as well as some medicinal properties like lowering blood cholesterol level, defense against cancer and invigorating hair growth [4]. Edible mushrooms are also rich in vitamins such as niacin, riboflavin, vitamin $D, C$, and $\mathrm{B}$ complex [5]. FAO recommended edible mushrooms as a food to meet protein requirement of developing countries where a large number of populations depends mainly on cereal crops [6].

Mushroom is an organic vegetable and the production of mushroom is an eco-friendly and profitable agribusiness but labour intensive [7]. It does not require any cultivable land and can be grown in room by racking vertically. Mushroom cultivation can help reduce vulnerability to poverty and strengthens livelihoods through the generation of a fast yielding and nutritious source of food and a reliable source of income [8]. Mushrooms are being grown on commercial scale in many parts of the world. The commercial cultivation first started in Europe with the beginning of last century but the history of mushroom production is very recent in Bangladesh. Wildly, 20 species of mushroom are grown in the country, of which 5-6 are poisonous; and the recommended species for cultivation are oyster (Pleurotus spp.) and white button mushroom (Agaricus bisporus) [9]. Bangladesh is one of the most suitable countries in the world for mushroom cultivation owing to its favorable climate with low production cost, availability of growing substrates and high market value $[10,11]$. Mushroom can be easily grown on cellulose, hemicellulose and lignin rich organic substrates such as sawdust, leaves and other agro byproducts $[12,13]$.

The nutritional status of Bangladeshi people is a matter of great concern as more than half of the populations have been suffering from malnutrition [14]. Consumption of mushrooms can relieve the suffering from malnutrition to some extent, because they produce in large quantities within a short period of time and provide more protein per unit area than any other crops [15]. Crop diversification and change of food habit are very crucial to build up the national health [16]. The demand and consumption of mushrooms are increasing day by day and mainly small entrepreneurs are producing and marketing mushrooms and mushroom based products in the country [17].

Though there is a huge prospect of mushroom production in Bangladesh, there are some problems during cultivation and marketing; which are essential to be addressed and as such steps could be taken to boost production of this crop [18]. On the other hand, mushrooms have not got much attention as a food item in Bangladesh due to negative attitude of the people thinking it as "toad-stool" and feeling doubt whether it is Halal or not [19]. Despite the technology of mushroom cultivation is somewhat recent innovation and incorporation of this non-conventional crop in existing agricultural system can help in improving the social as well as economic status of the rural farmers and sub-urban dwellers. Considering the importance of mushroom production, Government of Bangladesh has established Mushroom Development Institute (MDI) in 2014 at Saver of Dhaka to impart training and 
promotion of mushroom farming, previously which was named National Mushroom Development and Extension Centre (NAMDEC).

However, very little information is known about the status of mushroom production, potential benefits, challenges and opportunities in Bangladesh. Therefore, this study so far reviews the available information on mushroom with a view to summarize the overall aspects of its production and marketing. Finally, few suggestions have been recommended which may help boost mushroom production and the way forward of this sector in Bangladesh.

\section{BENEFITS OF MUSHROOM}

\subsection{Nutritional Benefits}

It is well recognized that mushroom contains all essential components of a balanced diet. Nutrient content of mushrooms varied depending on the species and has been shown in Table 1. In fact, mushroom is rich in digestible essential amino acid, rich protein, vitamins and minerals but low volume of high-quality unsaturated fat and water-soluble carbohydrate $[8,20]$. In addition, it is rich in folic acid, vitamin B complex, phosphorus, potassium, calcium, copper, iron and other essential elements [21]. Minerals content also varied among different species of mushroom. Khan et al. [22] assessed the amount of different minerals in various mushroom species and found 15.4-69 mg Fe, 16-275 mg $\mathrm{Ca}, 11.1-28.8 \mathrm{mg} \mathrm{Zn}, 14-31.4 \mathrm{mg} \mathrm{Mg}$ and 685$1740 \mathrm{mg} \mathrm{P}$ per $100 \mathrm{~g}$ of dry mushrooms. The metabolizable energy content of different mushroom species ranges from 150-300 $\mathrm{Kcal} / 100 \mathrm{~g}$ of dry mushroom [22]. Nutritional index of mushrooms ranges from 6 to 31 depending on species which indicates high nutritional value of this food.However, comparative nutritional index of mushrooms with other foods is presented in Fig. 1. In general, edible mushrooms are low in fat and calories, rich in vitamins and minerals [23], contain more protein than any other food of plant origin [24].

Table 1. Nutrient contents of different species of mushroom

\begin{tabular}{llllllll}
\hline Mushroom spp. & $\begin{array}{l}\text { Moisture } \\
\text { (\%) }\end{array}$ & $\begin{array}{l}\text { Drymatter } \\
\text { (\%) }\end{array}$ & \multicolumn{5}{c}{ Dry weight basis (g/100 g of mushroom) } \\
\cline { 4 - 8 } & 89.4 & 10.6 & Protein & Lipid & Carbohydrate & Fiber & Ash \\
\hline A. bisporous & 89.6 & 10.0 & 23.6 & 21.2 & 7.8 \\
P. ostreatus & 89.4 & 10.6 & 28.4 & 4.7 & 35.4 & 21.8 & 8.6 \\
P. citrinopleatus & 88.0 & 12.0 & 30.3 & 3.4 & 33.1 & 22.2 & 11.0 \\
P. eryngii & 85.0 & 15.0 & 23.5 & 11.9 & 29.9 & 25.8 & 8.9 \\
C. comatus & 90.5 & 9.5 & 24.2 & 7.3 & 32.1 & 27.9 & 8.5 \\
H. ulmarius & 87.1 & 12.9 & 31.3 & 1.0 & 49.9 & 8.6 & 9.2 \\
A. aegerita & 91.4 & 8.6 & 27.6 & 5.4 & 28.7 & 26.7 & 11.6 \\
A. polytricha & 85.0 & 15.0 & 18.3 & 2.0 & 18.9 & 50.0 & 10.8 \\
V. volvacea & 89.1 & 10.9 & 20.0 & 10.8 & 42.0 & 15.2 & 12.0 \\
L. edodes & 78.5 & 21.5 & 27.0 & 7.2 & 21.7 & 38.3 & 5.8 \\
G. lucidum & 70.2 & 29.8 & 26.4 & 2.7 & 12.8 & 51.5 & 6.5 \\
C. versicolor & 58.2 & 41.8 & 26.0 & 3.7 & 9.2 & 50.1 & 11.0 \\
\hline
\end{tabular}

Values are mean ( $n=5)$; Source: Khan et al. [22]; Ahmed et al. [25]

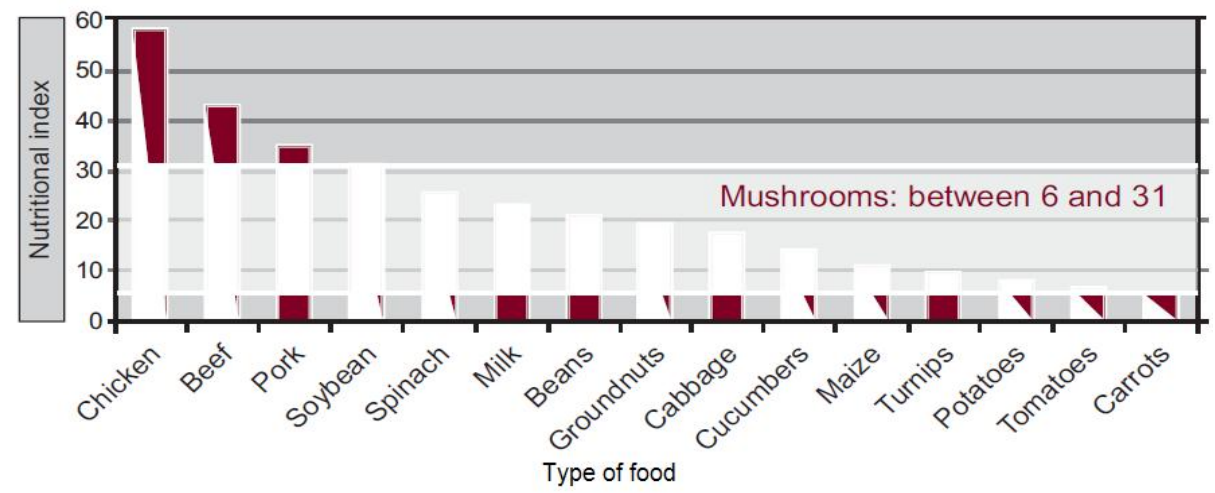

Fig. 1. A comparison of the nutritional index of different foods with mushrooms Source: Marshall and Nair [8] 


\subsection{Medicinal Benefits}

Mushrooms are reported to have high medicinal properties. About $6 \%$ of edible mushrooms are known to have medicinal properties and can be found in health tonics, tinctures, teas, soups and herbal formulae [8]. Edible mushrooms have been used as important ingredient in the production of certain pharmaceutical products for their medicinal values $[1,26,27]$. Worldwide, Shiitake (Lentinula edodes) and Reishi (Ganoderma lucidum) mushrooms are highly recognized for their medicinal values and said to have antitumor, antiviral properties like anti-HIV and anti-hepatitis $B$ and remove serum cholesterol from the blood stream $[8,28]$. Reishi mushroom is known as the 'mushroom of immortality' [29]. Mushroom contains natural ingredients which are very effective in normalizing blood pressure, lowering blood cholesterol and blood sugar level, protecting the liver, controlling some types of cancers, boosting the body's immune systems and hence in promoting general fitness [21,23].

\subsection{Economic Benefits}

Mushrooms constitute one of the most promising resources for promoting rapid socioeconomic development [1]. Cultivation of mushroom is a source of national income as well as a means of poverty alleviation. The production of mushroom creates a large number of direct and indirect employment opportunities in cultivation as well as in marketing activities as a labor-intensive management and offering opportunities for processing enterprises [8,21]. Mushroom farming needs low capital, low technical knowledge and even in an indoor setting it is possible to cultivate mushroom in a small scale and one can easily get high return with low investment; Women can cultivate mushroom in their homes like rearing poultry with a little capital $[19,21,30]$. Therefore, mushroom cultivation not only empower rural women but also alleviate poverty from the grass root level.

\subsection{Environmental Benefits}

Mushrooms play an important ecological role in the management of ecosystems [1]. Indirectly, mushroom cultivation is a bioconversion process of organic substances which provides opportunities for the recycling of organic matter thus reduces pollution. Substances used in mushroom cultivation are applied as organic manures to the land after harvesting of mushrooms. Mushroom cultivation is an appropriate technology for management of agricultural and agro-industrial residues [31].

\section{MUSHROOM PRODUCTION IN BANGLADESH}

\subsection{Current Status of Mushroom Production}

Mushroom production and consumption are getting popularity among the Bangladeshi people. Its production is increasing day by day in Bangladesh as evident by almost four times higher mushroom is produced in 2018-19 compared to 2009-10. An incremental trend of mushroom production was observed over last ten years (Table 2). Mushroom production and consumption in Bangladesh are increasing through using MDI developed technologies and low-cost farmer's friendly equipment [32]. Though the mushroom production is increased in Bangladesh but could not meet the demand yet.The cost of importing mushrooms in the country is estimated to be BDT 85 to 90 crore per year [33]. The global mushroom production exceeds ten million tons [1,34], of which the country contributes only 0.04 million tons. Mushrooms are commercially being cultivated in more than 25 districts of Bangladesh [19].

\subsection{Production Efficiency in Small Scale Mushroom Farms}

Small scale mushroom production is increasing among rural farmers of Bangladesh with diverse production efficiency. Mushroom farming in 10 different sized farms showed noticeable difference of monthly production (Fig. 2). Despite of larger farm (32 sq ft) the lower production efficiency comparedto the smallerfarms (15-30 $\mathrm{sq} \mathrm{ft}$ ) could be due to the difference of management.

\subsection{Socio-economic Status of Mushroom Grower}

Educated young people are mainly involved in mushrooms production in Bangladesh (Table 3). Study on mushroom grower in Savar upazila revealed that women involvement was very high $(82.6 \%)$ in mushroom production. The study also reported that $68.6 \%$ farmer took mushroom farming as their primary occupation and remaining $31.4 \%$ practiced it as secondary occupation [17]. The investment on small scale mushroom farming was found to be very low; consequently, daily production of mushroom was also low and $80 \%$ farms produced only $1-5 \mathrm{~kg}$ and other $20 \%$ produced $5-10 \mathrm{~kg}$ (Table 3 ). 
Table 2. Mushroom production in Bangladesh

\begin{tabular}{lll}
\hline Year & Production (Metric ton) & \% Change from previous year \\
\hline $2009-2010$ & 10500 & +31.25 \\
$2010-2011$ & 14500 & +38.10 \\
$2011-2012$ & 18000 & +24.14 \\
$2012-2013$ & 22000 & +18.18 \\
$2013-2014$ & 30000 & +36.36 \\
$2014-2015$ & 32000 & +6.67 \\
$2015-2016$ & 34000 & +6.25 \\
$2016-2017$ & 36000 & +5.88 \\
$2017-2018$ & 37000 & +2.78 \\
$2018-2019$ & 40000 & +8.11 \\
\hline \multicolumn{2}{c}{ Source: MDI [35] }
\end{tabular}

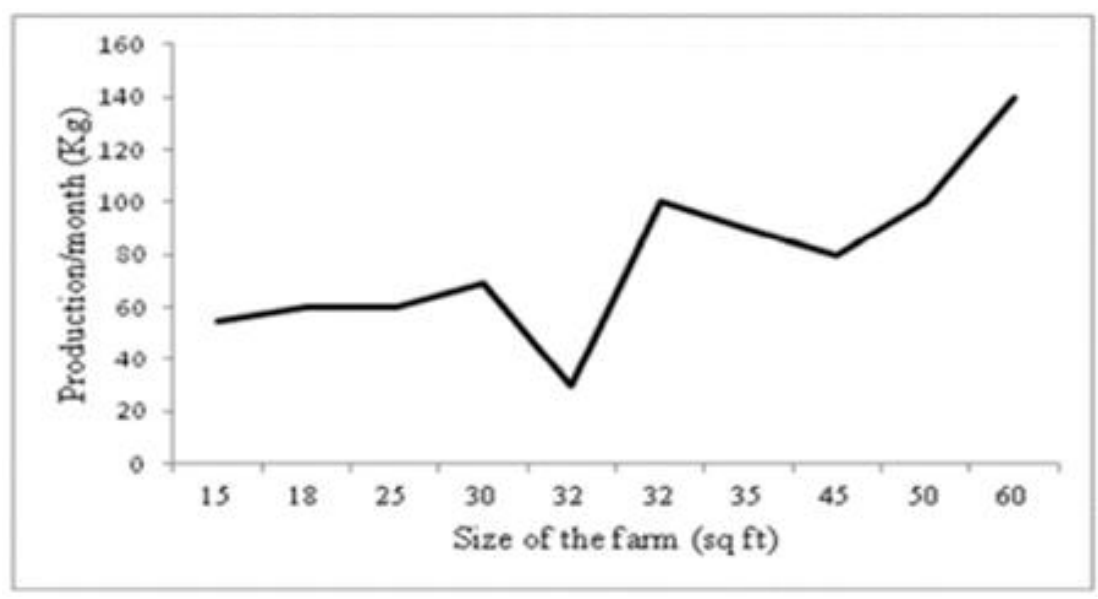

Fig. 2. Production of mushrooms in different sized farms Source: Easin et al. [19]

Table 3. Socio-economic attributes of mushroom entrepreneurs in the selected area of Bangladesh

\begin{tabular}{lll}
\hline Attributes & Category & $\%$ of entrepreneurs \\
\hline Age-class(years) & $<20$ & 16 \\
& $20-30$ & 40 \\
& $30-40$ & 28 \\
& $>40$ & 16 \\
\hline Educational status & Illiterate & - \\
& Primary & 20 \\
& Secondary & 60 \\
& Higher secondary & 20 \\
\hline Amount of investment(BDT) & $<5000$ & 40 \\
& $5000-10000$ & 30 \\
& $10000-50000$ & 15 \\
& $50000-100000$ & 10 \\
& $>100000$ & 5 \\
\hline Production Range(Kg/Day) & $1-3$ & 70 \\
& $3-5$ & 10 \\
& $5-10$ & 20 \\
\hline
\end{tabular}




\subsection{Cultivated Species and Varieties of Mushroom}

There are several mushroom species and varieties, which have so far been produced or attempted for production in Bangladesh (Table 4). MDI has already been released 9 varieties of different mushroom species suitable for different seasons of Bangladesh (Table 4). All varieties of mushroom were registered in 2012 [35]. A study on mushroom growers in Savar upazila of Dhaka district revealed that farmers preferred oyster mushroom followed by reishi, straw, milky, button and shiitake for cultivation (Fig. 3). Mainly, oyster mushroom has been commercially adopted and extensively produced across the country due to its high market demand $[36,37]$ and suitabilityunder Bangladesh condition [38]. There are also some natural mushrooms like Shammo oal and Harin bash oal available in Chittagong Hill Tracts, and very popular to hill dwellers due to its aromatic fragrance [39].

Table 4. Cultivated species and varieties of mushroom in Bangladesh

\begin{tabular}{|c|c|c|c|}
\hline $\begin{array}{l}\text { Mushroom } \\
\text { Species }\end{array}$ & Scientific Name & Variety name & Features \\
\hline Oyster & Pleurotus spp. & $\begin{array}{l}\text { NOM-1 (NAMDEC } \\
\text { Oyster Mushroom 1), } \\
\text { NOM-2, NOM-3, NOM-4, } \\
\text { NOM-5, and NOM-6 }\end{array}$ & $\begin{array}{l}\text { Biological efficiency (BE) more } \\
\text { than } 100 \% \text { and can grow } \\
\text { throughout the year }\end{array}$ \\
\hline Shiitake & Lentinus edodes & $\begin{array}{l}\text { NAMDEC Shiitake } \\
\text { Mushroom } 1\end{array}$ & $\begin{array}{l}\text { High nutritional and medicinal } \\
\text { value, } \mathrm{BE} \text { more than } 70 \%\end{array}$ \\
\hline Reishi & $\begin{array}{l}\text { Ganoderma } \\
\text { lucidum }\end{array}$ & $\begin{array}{l}\text { NAMDEC Reishi } \\
\text { Mushroom } 1\end{array}$ & $\begin{array}{l}\text { High medicinal value and } \mathrm{BE} \\
28 \%\end{array}$ \\
\hline Milky White & Calocybe indica & $\begin{array}{l}\text { NAMDEC Milky } \\
\text { Mushroom } 1\end{array}$ & $\begin{array}{l}\text { Very nutritious and tasty } \\
\text { mushroom, BE } 100 \%\end{array}$ \\
\hline White Button & Agaricus bisporus & - & $\begin{array}{l}\text { High value mushroom and grown } \\
\text { in winter, } B E 13 \%\end{array}$ \\
\hline Straw & $\begin{array}{l}\text { Volvariella } \\
\text { volvacea }\end{array}$ & - & $\begin{array}{l}\text { Grown in summer season and } \\
\text { BE } 30 \%\end{array}$ \\
\hline Wood Ear & $\begin{array}{l}\text { Auricularia } \\
\text { auricula }\end{array}$ & - & $\begin{array}{l}\text { Year-round and rich in iron, } \\
\text { protein and vitamins } B_{1} \text { and } B_{2}\end{array}$ \\
\hline Enoki & Flammjlina flutes & - & $\begin{array}{l}\text { Highly rich in vitamins and } \\
\text { minerals }\end{array}$ \\
\hline Monkey Head & $\begin{array}{l}\text { Hericium } \\
\text { erinaceus }\end{array}$ & - & $\begin{array}{l}\text { High medicinal value can } \\
\text { improve nervous system }\end{array}$ \\
\hline
\end{tabular}

\section{Percentage}

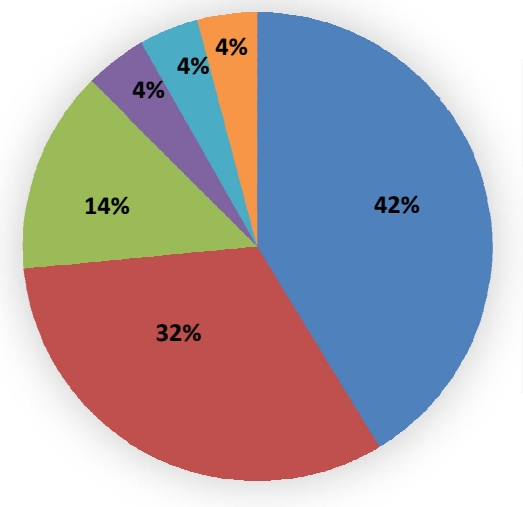

Oyster

Reishi

Straw

Button

Milky

Shiitake

Fig. 3. Frequency distribution of cultivated species Source: Rahman [18] 


\subsection{Mushroom Cultivation Method and Season}

There are several methods of mushroom cultivation like bag cultivation, bottle cultivation, log cultivation etc. in the world. In Bangladesh, bag cultivation method is very popular and extensively practiced throughout the country. Though 5-6 flushes may be harvested from each bag, the first three harvests are very important for commercial production. For each $10 \mathrm{~kg}$ of substrate used, depending upon species up to 20 $\mathrm{kg}$ of mushroom can be harvested from the first 3-4 flushes [9]. MDI has developed a production calendar for mushroom cultivation in Bangladesh (Fig. 4). Growing season of mushrooms are variety and strain specific; most of the varieties and strains of oyster, shiitake and button mushrooms grow well in winter season whereas milky, reishi, and straw mushrooms are suitable for monsoon. Some strains of oyster and ear mushrooms can be grown throughout the year.

\subsection{Performance of Mushroom}

\subsubsection{Performance of selected oyster strains}

Emergence and number of primordia, number and weight of fully developed fruiting bodies, total yield, and biological efficiency of some oyster mushrooms is shown in Table 5. All the strains of Pleurotus mushroom produced first primordia after 7-10 days of scraping. The fastest primordia induction (IT) was recorded in the strains PHK and PO2, whereas the strains PG1 and PG3 showed the slowest primordia emergence. The highest number of primordia per bag $(500 \mathrm{~g})$ was produced in PHK and the lowest number was found in PO2 strain. The strain PHK produced the highest number of mature fruiting bodies, while the lowest was found in the strain PG3. The heaviest single fruiting body was found in
PG1 strain followed by the strain PG3. Among the tested strains, both the highest biological and economic yields were reflected in PG1 strain and the lowest were recorded in $\mathrm{PO} 3$. The highest (95.8\%) biological efficiency (BE) was recorded in PG1, whereas the lowest $(56.4 \%)$ in PO3 strain. Many authors have been reported similar findings in different oyster mushroom [11,40,41, 42].

\subsubsection{Effect of growing season on the performance of oyster mushroom}

The performance of some selected species of oyster mushroom in different seasonal conditions of Bangladesh is shown in Fig. 5. Study on the biological yield of selected oyster species showed noticeable variation in different months of the year and ranged $46-239 \mathrm{~g}$ (Fig. 5a). The highest yield was recorded in $P$. high king in December and the lowest in $P$. ostreatus in September. Both the species $P$. ostreatus and $P$. florida gave the maximum yields (232 and $234 \mathrm{~g}$ ) in January and the minimum (46 and $51 \mathrm{~g}$ ) in September. The species $P$. sajor-caju and $P$. high king produced maximum yields (193 and $239 \mathrm{~g}$ ) in December; the minimum yield of $P$. sajor-caju (51 g) and $P$. high king (50 g) were recorded in September and August, respectively. The BE of selected oyster species varied from 23 to $119.5 \%$ in different months of a year and showed the similar trends of biological yield for all the species (Fig. 5b). It can be concluded that the performance of oyster mushroom was found better during December-February; the performance was found to be decreased from March and moderate in April-July. During August to October, the performance was at minimum level and again, increased from November. Better performance of oyster mushrooms during winter might be due to cold climatic conditions.

Table 5. Performance of some oyster strains (Pleurotus spp.)

\begin{tabular}{llllllll}
\hline \multirow{2}{*}{$\begin{array}{l}\text { Oyster } \\
\text { strains }\end{array}$} & \multicolumn{2}{c}{ Primordia } & \multicolumn{2}{c}{ Fruiting body } & \multicolumn{2}{c}{ Total yield (g/bag) } & \multirow{2}{*}{ BE (\%) } \\
\cline { 2 - 7 } & IT (days) & Number & Number & Weight (g) & Biological & Economic & \\
\hline PHK & $7.6 \mathrm{~b}$ & $197.8 \mathrm{a}$ & $60.4 \mathrm{a}$ & $2.4 \mathrm{~d}$ & $178.6 \mathrm{c}$ & $175.7 \mathrm{~b}$ & $61.5 \mathrm{c}$ \\
PO3 & $8.0 \mathrm{~b}$ & $84.4 \mathrm{~b}$ & $49.4 \mathrm{~b}$ & $2.8 \mathrm{~cd}$ & $163.8 \mathrm{~d}$ & $157.8 \mathrm{c}$ & $56.4 \mathrm{~d}$ \\
PG1 & $9.8 \mathrm{a}$ & $191.6 \mathrm{a}$ & $30.4 \mathrm{~cd}$ & $7.4 \mathrm{a}$ & $278.0 \mathrm{a}$ & $273.6 \mathrm{a}$ & $95.8 \mathrm{a}$ \\
PG3 & $10.2 \mathrm{a}$ & $184.6 \mathrm{a}$ & $25.0 \mathrm{~d}$ & $5.6 \mathrm{~b}$ & $188.5 \mathrm{~b}$ & $185.2 \mathrm{~b}$ & $65.0 \mathrm{~b}$ \\
PO2 & $7.6 \mathrm{~b}$ & $71.4 \mathrm{~b}$ & $34.6 \mathrm{c}$ & $3.4 \mathrm{c}$ & $171.4 \mathrm{~cd}$ & $163.2 \mathrm{c}$ & $59.1 \mathrm{~cd}$ \\
\hline
\end{tabular}

Different alphabetical letters in each column indicates significant differences among different species at $1 \%$ level of probability. PHK (P. high-king), PO3 ( $P$. ostreatus), PG1 ( $P$. geesteranus), PG3 ( $P$. geesteranus), and PO2 (P. ostreatus); Source: Ahmed et al. [25] 


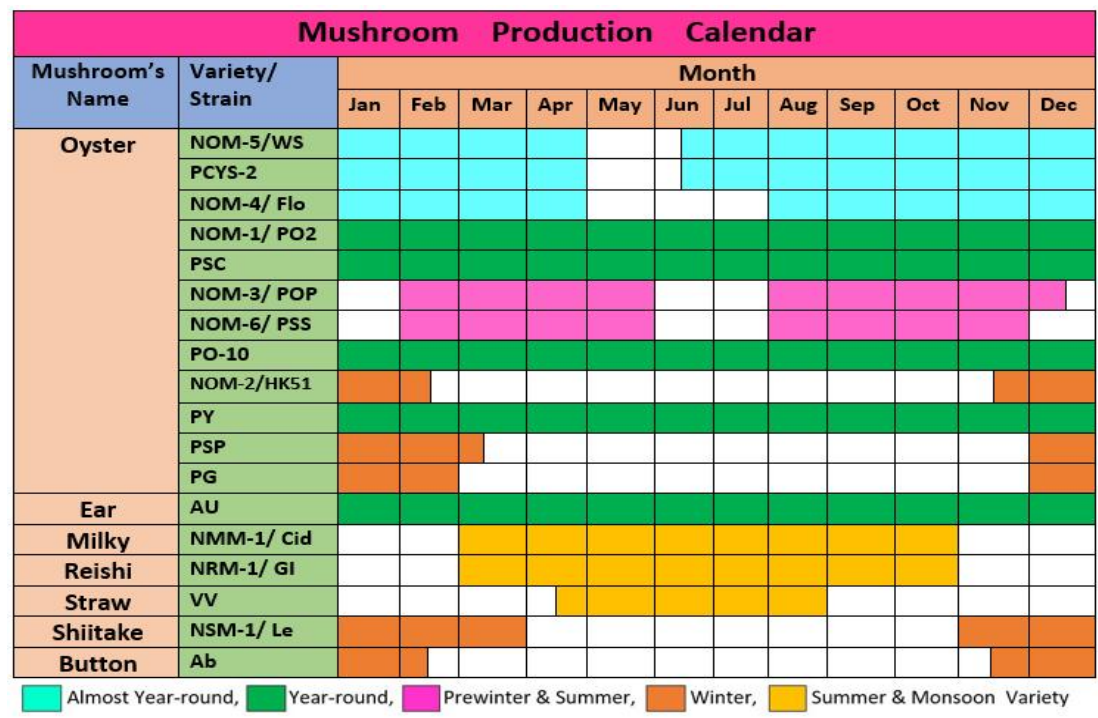

Fig. 4. Mushroom production calendar of Bangladesh
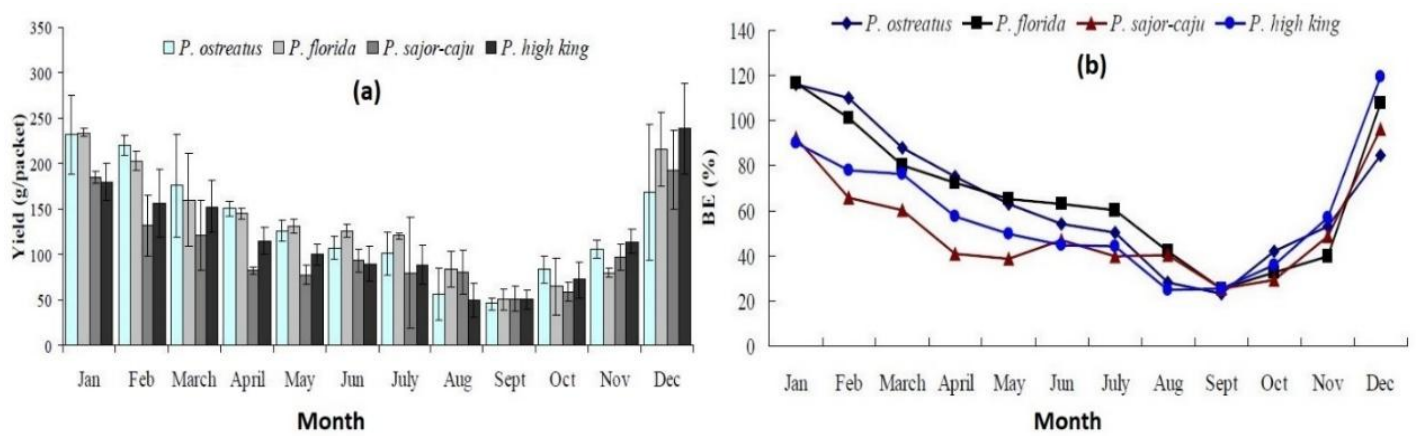

Jan Feb March April May Jun July Aug Sept Oet Nov Dec Month

Fig. 5. (a) Biological yield (g/500 g packet) and (b) Biological Efficiency (BE) of selected Pleurotus spp. in different months of the year

Vertical bars indicate standard errors; Source: Uddin et al. [11]

Table 6. Gross margin, net return and Benefit Cost Ratio (BCR) of mushroom

\begin{tabular}{ll}
\hline Particulars & BDT \\
\hline 1. Gross/ Total Revenue & 64826 \\
2. Total variable cost & 26036 \\
3. Total cost & 41938 \\
4. Gross Margin (GM) & 38790 \\
5. Net Return/ Profit & 22888 \\
6. Benefit Cost Ratio (BCR) & 1.55 \\
\hline \multicolumn{2}{c}{ Duration of mushroom cultivation is 3 months. Thus, all costs are calculated based on 3 months } \\
\end{tabular}

\subsection{Economic Performance of Mushroom}

Mushroom cultivation is highly profitable agribusiness compared to vegetables due to its high price in the market. A study on economics of mushroom revealed that the average gross margin was BDT 38790 and average net return was BDT 22888 with the average BCR 1.55
(Table 6). Cultivation of oyster mushroom on different sawdust showed high BCR which ranged from 3.62-4.25 [4]. High BCR (2.24) of mushroom farming as a small-scale family enterprise was reported by Easin et al. [19]. The comparative profitability of rice, wheat and mushroom was studied and it indicated that mushroom cultivation is the lucrative one [10]. 


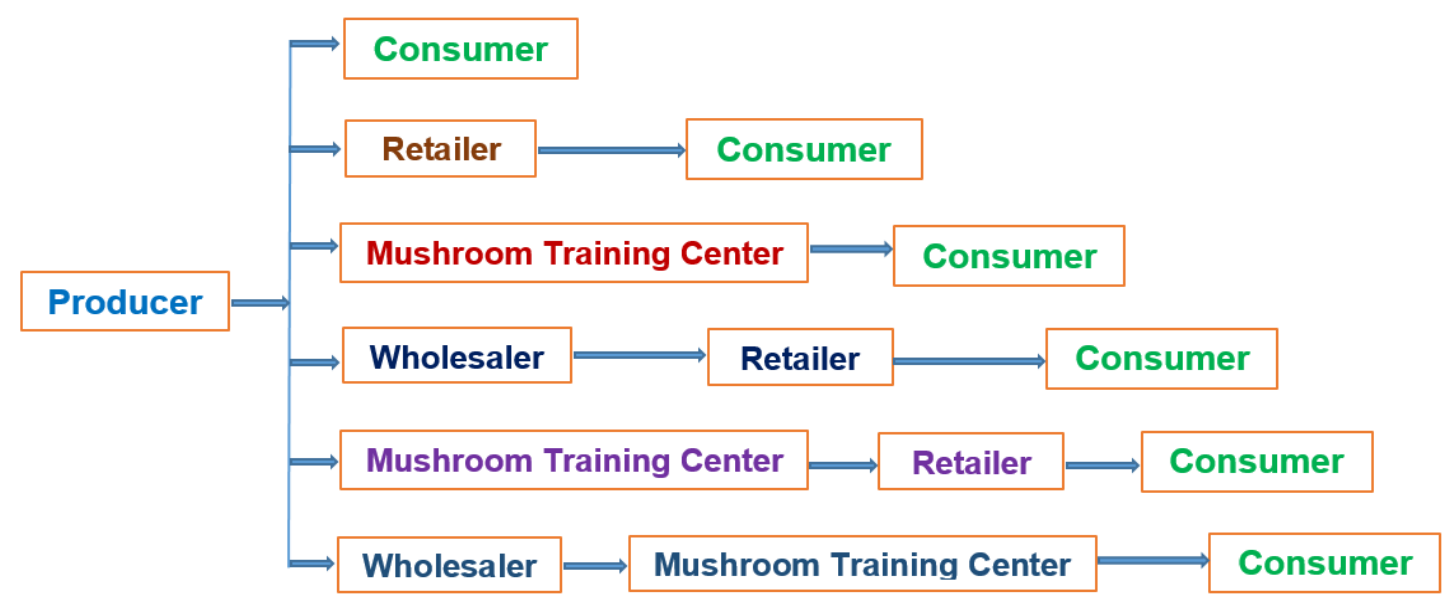

Fig. 6. Marketing channel of mushroom in Bangladesh Sources: Easin et al. [19]; Islam et al. [21]; Barmon et al. [43]

\subsection{Marketing Channel and Market of Mushrooms in Bangladesh}

The existing marketing channel of mushroom business reveals involvement of three intermediaries; such as retailer, mushroom training center and wholesalers who bring the product from producers to ultimate consumers (Fig. 6). The ultimate consumer of the mushroom is the local resident or the restaurant who hardly buy from the producers. Involvement of large number of intermediaries in mushroom marketing is due to lack of developed marketing system in rural level. Absence of organized marketing structure was found to force the growers to sell the mushrooms to the intermediaries [19]. Basically, rich and middle-income people are the main consumers of mushrooms in Bangladesh [43]. Oyster mushroom is very popular and sells to a relatively small niche market, comprising urban residents, institutional buyers such as restaurants, big mushroom farms, NGOs, school, college, university, and cantonment canteens, and expatriates of metro city [44]. Mainly, Button (Agaricus bisporus) and Reishi (Ganoderma lucidum) mushrooms are used in the Chinese restaurants and Pharmaceutical companies, of which mostly are imported [19].

\section{CHALLENGES OF MUSHROOM PRODUCTION IN BANGLADESH}

Although mushroom cultivation getting popularity among the farmers, there are some problems which stagnate the mushroom production in Bangladesh. Barman et al. [43] and Rahman [18] noted the following problems of mushrooms production during cultivation and marketing in Bangladesh:

\section{Problems confronting during production:}

- Lack of cultivation house

- Capital crisis

- Insects attack (flies and cockroach)

- Lack of the availability of quality spawn

- High price of raw materials

- Lack of equipment's (Air conditioner, sterilization chamber, Water tank, Steel rack etc.)

- High temperature in summer

- Lack of trained and experienced labour

- Heavy rainfall during monsoon

- Very low temperature in winter

- Time maintaining

- Inappropriate timing of production

Problems confronting during marketing:

- Lack of available markets

- High transportation cost

- Large number of middlemen

- Very limited wholesale market

- Unknown product to general consumers

- Lacking of advertising

- Absence of storage facilities

\section{PROSPECTS OF MUSHROOM PRODUCTION IN BANGLADESH}

Bangladesh is an agrarian and one of the most densely populated countries in the world is suffering from protein malnutrition with high proportion of poverty. According to recent estimates, $21.8 \%$ population lives under the 
poverty line [45]. The economy of Bangladesh is burdened with low per capita income and unemployment in the background of overpopulation. Total population of the country is 165.13 million [46], out of which only 59.5 million [47] are employed. On the other hand, the unemployed population in our country is 2.68 million out of which 1.33 million is female [30]. Almost all the arable land of the country is already under cultivation, therefore there exists a limited scope for expanding the cropland and cropping intensity [48]. Under this situation, mushroom cultivation could be a new hope for Bangladesh due to its climatic condition which is fairly favorable for high volume of mushroom production $[40,49]$.

There is a huge prospect of mushroom cultivation in Bangladesh. It can play an important role in eradicating malnutrition, one of the main problems of the people, and preventing diseases. By mushroom cultivation it is possible to alleviate poverty and providing employment for educated unemployed, youths, adolescents and women. Mushrooms cultivation does not require access to land and can be grown in room by racking vertically. The substrates required for mushroom production like sawdust, rice straw, wheat straw, sugarcane baggage, corncob, fallen leaves, water hyacinth, banana leaves, waste paper, used cotton etc. are always available and cheap, and even no materials are required to import from abroad for its cultivation. More than 50 million MT rice and wheat straws are being produced in Bangladesh; By using only 15\% (7.5 million MT) of these straw, 7.5 million MT of mushrooms could be produced in non-arable land of the country and the economic value of these production is about 15 thousand core BDT [30]. There will be no feed crisis for livestocks rearing for using this amount of straw in mushroom cultivation [30]. Moreover, other agrochemicals (chemical fertilizers, pesticides, and growth hormones) are not necessary for mushrooms cultivation. This farming requires little capital, short time and trouble-free technique and it provide quick monetary return. Capital return as well as benefit per unit area of mushroom production is higher than any other vegetable in our country [18] and small-scale growing does not include any significant capital investment [8]. Though mushrooms cultivation is a labour intensive job; young to old people, women and even physically disable people can do these activities. Mushroom cultivation is also a type of organic waste recycling process and worn substrate of it is one of the best sources of organic fertilizer for the soil. The most important thing is that mushroom can be processed in the industries to produce different types of export oriented mushroom product and medicine.

Mushroom could be used in making ready to eat food (fry, crispy, susliks, noodles etc.) and processed food pack item (pickle, halua, chutney, cake, tea, biscuits etc.). In addition, mushroom could be processed in powdered form, capsule form, canned products as well as mushroom enriched cosmetics (soap, toothpaste, cream, oil etc.). Hence, it can also generate huge employment opportunities. Mushroom farming is a viable and attractive activity for both rural farmers and peri-urban dwellers. Value addition to ancient products through industrial processing offer great opportunities to improve the livelihood of the peripheral rural people [1]. Mushrooms cultivation may be "a lifeboat" for survival of the marginal landless people who do not have any land other than their houses and can establish as a cottage industry and create a huge prospect for export [50]. The cultivation of mushroom is one of the lucrative agricultural job. Mushroom is an export-oriented agro product and its demand is very high in the international markets [10]. Its cultivation is a vibrant example of small-scale farming in many developing countries that has alleviated rural poverty and improved diversification of agricultural production [51].

\section{CONCLUSION}

Mushroom has been consumed as a nutritious food and dietary supplement in Bangladesh. The mushroom production reaches 40000 metric-tons in the last year. There are many mushroom species cultivated in the country, among them oyster is cultivated extensively throughout the year. Although having some problems during production and marketing there is a huge prospect of mushroom business in Bangladesh with the background of huge unemployment and malnutrition. Small scale mushroom farming has the opportunity to farmers and small entrepreneurs without much land, capital and technical knowledge to eradicate poverty within short time. Mushroom farming provides income opportunities for disadvantaged groups i.e. landless, rural women, adolescents and physically disables people. Development of mushroom based industry also creates a scope to export mushroom products, thus it can generate employment opportunity for unemployed. Based on the above facts, some suggestion can therefore, be recommended: 
Strengthening technical support to the farmers, easy capital supply, increase the supply of quality spawn, establishment of marketing structure, promotion of mushroom in new areas, establishment of storage facilities, strengthening the institutional capacity of MDI are different way to develop the mushroom sector of Bangladesh. The DAE of the government should establish more extension program to increase the production of mushroom and campaigns for its consumption.

\section{ACKNOWLEDGEMENTS}

Authors would like to thank Dr. Nirod Chandra Sarker, Deputy Director, MDI and Dr. Akther Jahan Kakon, Mushroom Specialist, MDI, Savar, Dhaka, for supporting us through providing valuable information on mushroom.

\section{COMPETING INTERESTS}

Authors have declared that no competing interests exist.

\section{REFERENCES}

1. Martínez-lbarra E, Gómez-Martín MB, Armesto-López XA. Climatic and socioeconomic aspects of mushrooms: The case of Spain. Sustainability. 2019;11 (4):1030.

2. Kakon AJ, Choudhury MBK. Nutritional and medicinal perspective of Hericium mushroom. Bangladesh Journal of Mushroom. 2015;9(1):67-75.

3. Ng'etich OK, Nyamangyoku OI, Rono JJ, Niyokuri AN, Izamuhaye JC. Relative performance of oyster mushroom (Pleurotus florida) on agro-industrial and agricultural substrate. International Journal of Agronomy and Plant Production. 2013; 4(1):109-116.

4. Miah MN, Begum A, Shelly NJ, Bhattacharjya DK, Paul RK, Kabir $\mathrm{MH}$. Effect of different sawdust substrates on the growth, yield and proximate composition of white oyster mushroom (Pleurotus ostreatus). Bioresearch Communications. 2017;3(2):397-410.

5. Ahmed SA, Kadam JA, Mane VP, Patil SS, Baig MMV. Biological efficiency and nutritional contents of Pleurotus florida (Mont.) Singer cultivated on different agrowastes. Nature and Science. 2009;7(1): 44-48.
6. World Bank. World Development Reports. Oxford University Press, Inc., New York; 2004.

7. Chandha KL, Sharma SR. Advances in horticulture mushroom, Malhotra Publication House, New Delhi; 1995.

8. Marshall E, Nair NG. Make money by growing mushrooms. Food and Agriculture Organization of the United Nations (FAO), Rome; 2009.

9. Banglapedia. National Encyclopedia of Bangladesh; 2019.

(Accessed 10 December 2019)

Available:http://en.banglapedia.org/index.p hp?title=Mushroom

10. Imtiaj A, Rahman SA. Economic viability of mushrooms cultivation to poverty reduction in Bangladesh. Tropical and Subtropical Agroecosystems. 2008;8:93-99.

11. Uddin MN, Yesmin S, Khan MA, Tania M, Moonmoon M, Ahmed S. Production of oyster mushrooms in different seasonal conditions of Bangladesh. Journal of scientific Research. 2011; 3(1):161-167.

12. Neupane $S$, Thakur V, Bhatta B, Pathak P, Gautam BB, Aryal L. Performance of different substrates on the production of oyster mushroom (Pleurotus florida) at Gokuleshwor, Darchula. International Journal of Scientific and Research Publications. 2018;8(6):231-240.

13. McGrath P. Water hyacinth spawns mushroom enterprise. New Agriculturalist, Earthscan, UK; 2003.

14. ICDDRB. A brief guide to malnutrition and its impact globally and in Bangladesh; 2019.

(Accessed on 12 December 2019)

Available:https://www.icddrb.org/newsand-events/press-corner/mediaresources/malnutrition

15. Gupta RS. Mushroom cultivation. Indian Horticulture. 1986;31(1):1.

16. Dey BC. Effect of materials, post composting supplements and plant growth regulators on the yield of white button mushroom and its marketing in Bangladesh. Doctoral Thesis, Department of Horticulture, BSMRAU, Gazipur; 2010.

17. Sarker NC, Kakon AJ, Amin R, Choudhury MBK. Microbiological assessment of mushroom capsules as food supplement produced by Bangladesh mushroom traders. Bangladesh Journal of Mushroom. 2015;9(1):43-47.

18. Rahman M. Problems and prospects of quality mushroom supply for domestic 
market. Ms Thesis, Department of Agribusiness and Marketing, Sher-eBangla Agricultural University, Dhaka; 2018.

19. Easin MN, Ahmed R, Alam MS, Reza MS, Ahmed KU. Mushroom cultivation as a small-scale family enterprise for the alternative income generation in rural Bangladesh. International Journal of Agriculture, Forestry and Fisheries. 2017; 5(1):1-8.

20. Boa ER. Wild edible fungi: A global overview of their use and importance to people (No. 17). Food and Agriculture Organization of the United Nations (FAO), Rome; 2004.

21. Islam MK, Khan $\mathrm{MMH}$, Islam MN. An unrealized manner for poverty alleviation: The mushroom industry. Dhaka University Journal of Marketing. 2013;16 (1):43-56.

22. Khan MA, Khan LA, Hossain MS, Tania M, Uddin MN. Investigation on the nutritional composition of the common edible and medicinal mushrooms cultivated in Bangladesh. Bangladesh Journal of Mushroom. 2009;3(1):21-28.

23. Alam N, Khan A, Hossain MS, Amin SR, Khan LA. Nutritional analysis of dietary mushroom Pleurotus florida Eger and Pleurotus sajor-caju (Fr.) Singer. Bangladesh Journal of Mushroom. 2007; 1(2):1-7.

24. Qin SX, Zhang HL, Ren LK, Yan XJ. Effect of different cultivation materials on nutritive composition of Pleurotus fruiting bodies. Edible fungi of China. 1989;3:1213.

25. Ahmed M, Abdullah N, Ahmed KU, Bhuyan MHM. Yield and nutritional composition of oyster mushroom strains newly introduced in Bangladesh. Pesquisa Agropecuária Brasileira. 2013;48(2):197-202.

26. Cheung LM, Cheung PCK. Mushroom extracts with antioxidant activity against lipid peroxidation. Food Chemistry. 2005; 89:403-409.

27. Hawksworth DL. Mushrooms: The extent of the unexplored potential. International Journal of Medicinal Mushrooms. 2001;3 (4):333-340.

28. Wasser SP. Shiitake (Lentinus edodes). Encyclopedia of Dietary Supplements; 2005.

29. Kaul TN. Biology and conservation of mushrooms. Oxford \& IBH Publishing Co. Pvt. Ltd. New Delhi. India; 2001.
30. Sarker NC. Mushroom: A promising crop for Bangladesh. 2019.

(Accessed 02 January, 2020)

Available:https://dailyasianage.com/news/2 11886/mushroom-a-promising-crop-forbangladesh

31. Chang ST, Miles PG. Mushroom biology A new discipline. Mycologist. 1992;6(2):6465.

32. Sarker NC. Agricultural development: Revolutionary tools for mushroom production in Bangladesh. 2020.

(Accessed on 24 January, 2020)

Available:https://https://dailyasianage.com/ news/215401/revolutionary-tools-formushroom-production-in-bangladesh

33. The Daily Ittefaq. Possibility of cultivating mushrooms in small capital; 2016.

(Accessed 10 December 2019)

Available:https://archive1.ittefaq.com.bd/pri nt-edition/econo/2016/04/23/115552.html

34. FAO (Food and Agriculture Organization). FAOSTAT: Crops; 2017.

(Accessed on 10 December 2019)

Available:http://www.fao.org/faostat/en/\#da ta/QC/visualize

35. MDI (Mushroom Development Institute). Annual Report 2018-19, Savar, Dhaka; 2019.

36. Khan MA, Amin SR, Uddin MN, Tania M, Alam N. Comparative study of the nutritional composition of oyster mushrooms cultivated in Bangladesh. Bangladesh Journal of Mushroom. 2008;2 (1):9-14.

37. Alam N, Amin R, Khan A, Ara I, Shim MJ, Lee MW, Lee UY, Lee TS. Comparative effects of oyster mushrooms on lipid profile, liver and kidney function in hypercholesterolemic rats. Mycobiology. 2009;37(1):37-42.

38. Amin SR, Sarker NC, Khair A, Alam N. Detection of novel supplements of paddy straw substrate on oyster mushroom cultivation. Bangladesh Journal of Mushroom. 2007;1(2):33-37.

39. Mahmud MA. Overview of mushroom development in Bangladesh. International Conference on Mycology and Mushrooms. September 12-14, San Antonio, USA; 2016.

40. Sarker NC, Hossain MM, Sultana N, Mian $\mathrm{IH}$, Karim AJMS, Amin SMR. Performance of different substrates on the growth and yield of Pleurotus ostreatus (Jacquin ex Fr.) Kummer. Bangladesh Journal of Mushroom. 2007;1(2):9-20. 
41. Islam MZ, Rahman $M H$, Hafiz $F$. Cultivation of oyster mushroom (Pleurotus flabellatus) on different substrates. International Journal of Sustainable Crop Production. 2009;4(1):45-48.

42. Mondal SR, Rehana J, Noman MS, Adhikary SK. Comparative study on growth and yield performance of oyster mushroom (Pleurotus florida) on different substrates. Journal of the Bangladesh Agricultural University. 2010;8(2):213-220.

43. Barmon BK, Sharmin I, Abbasi PK, Mamun A. Economics of mushroom (Agaricus bisporus) production in a selected Upazila of Bangladesh. The Agriculturists. 2012;10 (2):77-89.

44. Zamil MF, Cadilhon JJ. Developing small production and marketing enterprises: Mushroom contract farming in Bangladesh. Development in Practice. 2009;19(7):923932.

45. BBS (Bangladesh Bureau of Statistics). Poverty rate comes down at $21.8 \mathrm{pc}$ in 2018. The Daily Star. 2019.

(Accessed on 10 December 2019)

Available:https://www.thedailystar.net/coun try/news/poverty-rate-comes-down-218pc2018-bbs-1742953
46. BBS (Bangladesh Bureau of Statistics). Statistical Pocket Book 2018, Statistics and Informatics Division, Ministry of Planning, GoB, Dhaka; 2018a.

47. BBS (Bangladesh Bureau of Statistics). Bangladesh Statistics 2018. Statistics and Informatics Division, Ministry of Planning, GoB, Dhaka; 2018b.

48. Timsina J, Wolf J, Guilpart N, Van Bussel LG, Grassini P, Van Wart J, Hossain A, Rashid $\mathrm{H}$, Islam S, Van Ittersum MK. Can Bangladesh produce enough cereals to meet future demand?. Agricultural systems. 2018;163:36-44.

49. Rahman MS, Hossain KZ, Ali MS, Afroz F. Effectiveness of training programme on mushroom cultivation. International Journal of Science and Business. 2017;1(3):88102.

50. Shakil MH, Tasnia M, Munim ZH, Mehedi MHK. Mushroom as a mechanism to alleviate poverty, unemployment and malnutrition. Asian Business Review. 2014;4(3):109-112.

51. Godfrey EZ, Siti MK, Judith ZP. Effects of temperature and hydrogen peroxide on mycelial growth of eight Pleurotus strains. Scientia Horticulture. 2010;125:95-102.

(c) 2019 Ferdousi et al.; This is an Open Access article distributed under the terms of the Creative Commons Attribution License (http://creativecommons.org/licenses/by/4.0), which permits unrestricted use, distribution, and reproduction in any medium, provided the original work is properly cited.

Peer-review history:

The peer review history for this paper can be accessed here: http://www.sdiarticle4.com/review-history/55161 